\title{
Impact of Certain Insecticides on Chemical Composition of Greenhouse and Open Field Tomato Plants
}

\author{
Mohammed A. AL-EeD ${ }^{1}$
}

\begin{abstract}
The impact of four insecticides; pirimiphos-methyl, chlorpyrifos-ethyl, cypermethrin and fenvalerate, on the chemical composition of greenhouse and open field tomato were evaluated. Insecticides were applied at recommended rates that used to control the insect pests. Data of moisture and ash contents revealed no significant differences between the greenhouse treated and untreated plants. However, dramatic effects were observed between treated and untreated open field plants in which slight increase or decrease were recorded. Carbohydrate contents were significantly decreased in all insecticide treatments when compared with control in greenhouse. However, slight increase of carbohydrate contents was recorded in open field treated plants compared with the control. Moreover, data showed slight reduction of phosphorus and nitrogen contents in most of the insecticide treatments either in greenhouse or in open field plants. In the case of trace elements data showed an increase of iron, zinc and copper contents in greenhouse treated plants and reduction of manganese, zinc and Copper in open field treated plants. However, dramatic effects were observed in the case of iron in open field and manganese in greenhouse treated plants. In conclusion, the impact of insecticides on chemical composition of tomato plants might depend on the environmental factors and the chemical structure of insecticide.
\end{abstract}

\section{INTRODUCTION}

Widespread using of chemicals in modern agriculture creates many problems. One of these problems is the persisent residue of pesticides that accumulate in soil or in plant as results of improper applied of pesticides. Those residues could interfere or react with plant nutrients, affect transformation of nutrient elements in soil and availability of these nutrient elements that are essential for plant life (Album, 1952). Several researches investigated the effects of lethal and sub-lethal doses of organoPhosphorus insecticides as function of carbohydrate metabolism in some organisms and suggested that organophosphorus insecticides affect carbohydrate metabolism and consequently alter their metabolic functions to meet required energy demands under the insecticides toxic stress condition (Um et al., 1991; Rajamanar and Manohar, 1998; and George and Ambrose, 1999). Likewise, Gabr et al.(1989) studied the influence of metolachlor foliar spray on growth, carbohydrate content and photosynthetic activity in transplanted tomato plants. Gaweesh and El-Bially (1991) studied the response of rapeseed to some herbicides and they concluded that treatment with linuron resulted in greatest protein and carbohydrate and they found no significant correlation between the carbohydrate content and protein content of rape plants. However, there was significant correlation between carbohydrates and ash content. Sundaraj and Tamiselvan (1991) investigated the influence of deltamethrin on some biochemical parameters in cotton leaves and concluded that total sugar, leaf reducing sugar and total chlorophyll content increased with increasing frequency of deltamethrin application. Sana et al.(1993) and Sonna (1993) investigated the effect of some herbicides on yield and chemical composition of peanut seeds and maize plants and concluded that all herbicides slightly increased protein and total carbohydrate of seeds and maize grains. Also, Mohmoud et al.(1996) studied the residual effect of soil application of some pesticides on soybean and reported that pesticides decreased concentration of protein and carbohydrates. In the meantime, Szynal and Sykut (1993) and Sharma et al. (2000) studied the influence of treated wheat with herbicides on the macro and microelements content of the grain and straw composition. They concluded that herbicides generally increased grain $\mathrm{Ca}$ and $\mathrm{K}$ content and decreased $\mathrm{Mn}$ and $\mathrm{Zn}$ contents and in many cases the changes were not significant. Potassium, $\mathrm{Ca}, \mathrm{Mg}$ and $\mathrm{Na}$ concentrations of the treated straw were found to be different with respect to the untreated. Likewise, Gupta et al. (1989) studied the effect of herbicide treatments on nitrogen contents of wheat and lentil plants and concluded that all treatment reduced nitrogen contents in wheat and lentils plants. Further, Warman and Harvard (1997) studied the effect of pesticides on mineral contents of carrots and cabbage and concluded that five elements in carrots roots ( $\mathrm{N}, \mathrm{S}, \mathrm{Mn}, \mathrm{Cu}$ and $\mathrm{B})$ and two elements in carrots leaves ( $\mathrm{S}$ and $\mathrm{Na}$ ) were influenced by the treatment. In cabbages, N, Mn and Zn were affected.

The objective of this research was to determine the residual effect of pirimiphos-methyl,chlorpyrifos-ethyl,

\footnotetext{
${ }^{1}$ Department of Arid land Agriculture, College of Agricultural Food Sciences, King Faisal University, P.O.Box.

420, Al-Hassa 31982, Saudi Arabia

Received September 12.2007.Accepted. December 25.2007
} 
cypermethrin and fenvalerate on chemical composition of greenhouse and open field tomato plants.

\section{MATERIALS AND METHODS}

\section{Chemicals:}

Four insecticides were purchased locally and used for this experiment.Two of them belongs to organophosphates; Actellic (pirimiphos-methyl) O-(2diethylamino-6-methylpyrimidin-4-yl) O,O-dimethyl phosphoro-thioate, 50\% EC and Dursban (chlorpyrifosethyl)O,O-diethylO-(3,5,6-trichloro-2-pyridinyl)

phosphorothioate, $48 \%$ EC, was applied at rates of 2.0 $\mathrm{ml} /$ liter. The other two belongs to synthetic pyrethroids; Cypermethrin $( \pm) \alpha$-cyano-3-phenoxybenzyl $( \pm)$-cis, trans-3-(2,2-dichlorovinyl)-2,2-dimethyl-

cyclopropanecarboxylate, $10 \% \mathrm{EC}$ was applied at a rate of $0.5 \mathrm{ml} / 1$ and Sumicidin (fenvalerate) (RS)- $\alpha$-Cyano3-phenoxybenzyl (RS)-2-(4-Chlorophenyl)-3methylbutyrate, $20 \% \mathrm{EC}$ at rate of $0.75 \mathrm{ml} / \mathrm{l}$.

\section{Field Trials:}

The experiment was carried out at the King Faisal Research Station at Al-Hassa, Saudi Arabia. It was planned in randomize block design. Cultural practices were applied as recommended for commercial production of greenhouse and open field tomato. Insecticides applications were repeated three times at 15 days intervals. Three replicates were set up for each treatment. A hand operated knapsack sprayer was used to apply the insecticides. Samples of treated plants were taken twice after each spray treatment (one week each) to determine the following constituents; moisture, ash, carbohydrates, nitrogen, phosphorus, iron, copper, manganese and zinc contents.

\section{Determination}

The percent of moisture contents and ash was determined according to the AOAC method (1980). Carbohydrates were determined according to Pearson (1976). Total nitrogen and phosphorus were determined according to Cottenie (1980), while iron, copper, manganese and zinc were determined by the atomic absorption. Statistical analysis was carried out according to Snedecor and Cochran (1967).

\section{RESULTS AND DISCUSSION}

Effect of insecticides on moisture, ash and carbohydrate contents of tomato plants

\section{1- Greenhouse tomato plants}

Table 1 showed slight increase of moisture content in all insecticide treatments when compared with control. The percent of moisture reached 11.6, 11.6, 11.5, 11.9 and $11.4 \%$ in pirimiphos-methyl, chlorpyrifos-ethyl, cypermethrin, fenvalerate and control, respectively. Statistical analysis revealed no significant differences in the moisture content between all insecticides treatments and control. Same trend was observed in ash content whereas no significant differences between insecticides treatments when compared with control except for chlorpyrifos-ethyl treatment that showed a significant difference. However, the data showed significant reduction in carbohydrate contents of treated tomato plants when compared with control. The lowest percent of carbohydrates was recorded in pirimiphos-methyl treated plants where it reached $29 \%$ compared with $34.8 \%$ in the control.

\section{2- Open field tomato plants}

Table 1 showed no significant differences of both moisture and ash contents between insecticide treatments and the control plants. The moisture content reached 8.3, 8.0, 8.6 and $8.3 \%$ in pirimiphos-methyl, chlorpyrifos-ethyl, cypermethrin and fenvalerate treated plants, respectively while it was $8.8 \%$ in the control plants. However, the ash content reached 12, 13.5, 13.6 and $15.7 \%$ in fenvalerate, pirimiphos-methyl, chlorpyrifos-ethyl and cypermethrin treated plants, respectively, as compared with $14.7 \%$ in the control plants. In the case of carbohydrate contents, the data showed significant differences between fenvalerate treated plants and the other insecticide treatments and/or control, where carbohydrate content was $23.3 \%$ in fenvalerate treated plants compared with $20.6 \%$ in the control plants (Table 1). The data revealed that all the three tested components were higher in greenhouse plants than open field ones in all insecticide treatments.

Effect of insecticides on nitrogen and phosphorus of tomato plants

\section{1- Greenhouse tomato plants}

Table2 showed significant increase of Nitrogen contents in pirimiphos-methyl and cypermethrin treatments when compared with control, while no significant differences were recorded between both chlorpyrifos-ethyl or fenvalerate treatments and the control. However, no significant difference in the phosphorus content was recorded between treated and untreated plants.

\section{2- Open field tomato plants}

Table2 showed no significant differences of nitrogen content between insecticide treatments and the control plants. The nitrogen content ranged between 10 and $10.7 \mathrm{gm} / \mathrm{kg}$. D.M. in cypermethrin and chlorpyrifos-ethyl treated plants, respectively, while it was $10.6 \mathrm{gm} / \mathrm{kg}$.D.M. in the control plants. However, data of phosphorus content revealed no significant differences between pirimiphos-methyl or cypermethrin treated plants and control plants, while significant differences were observed between fenvalerate or 
Table1. Effect of some insecticides on moisture, ash and carbohydrate contents of greenhouse and open field tomato plants.

\begin{tabular}{|c|c|c|c|c|c|c|}
\hline \multirow[t]{2}{*}{ Insecticide } & \multicolumn{2}{|c|}{$\begin{array}{l}\text { Moisture contents } \\
(\%)\end{array}$} & \multicolumn{2}{|c|}{$\begin{array}{l}\text { Ash } \\
(\%)\end{array}$} & \multicolumn{2}{|c|}{$\begin{array}{c}\text { Carbohydrates } \\
(\%)\end{array}$} \\
\hline & $\begin{array}{l}\text { Green } \\
\text { H. }\end{array}$ & F. & $\begin{array}{l}\text { Green } \\
\text { H. }\end{array}$ & $\begin{array}{l}\text { Open } \\
\text { F. }\end{array}$ & $\begin{array}{l}\text { Green } \\
\mathbf{H}\end{array}$ & $\begin{array}{l}\text { Open } \\
\text { F. }\end{array}$ \\
\hline $\begin{array}{l}\text { Pirimiphos- } \\
\text { Methyl }\end{array}$ & $11.6^{*}$ & 8.5 & 21.8 & 13.5 & 29.0 & 21.7 \\
\hline $\begin{array}{l}\text { Clorpyrifos- } \\
\text { Ethyl }\end{array}$ & 11.6 & 8.0 & 22.9 & 13.6 & 32.3 & 21.2 \\
\hline Cypermethin & 11.5 & 8.6 & 21.3 & 15.7 & 32.0 & 21.1 \\
\hline Fenvalerate & 11.8 & 8.3 & 21.3 & 12.0 & 32.8 & 23.3 \\
\hline Control & 11.4 & 8.8 & 19.6 & 14.7 & 34.8 & 20.6 \\
\hline $\mathbf{L S D}_{0.05}$ & 0.4 & 0.4 & 2.0 & 2.8 & 1.0 & 2.1 \\
\hline
\end{tabular}

* Mean of 18 samples of six weeks of three insecticide sprays at 15 days intervals.

\# Greenhouse

*** Openfield

Table 2. Effect of some insecticides on Nitrogen and Phosphorus of greenhouse and open field tomato plants.

\begin{tabular}{lcc}
\hline Insecticide & $\begin{array}{c}\text { Nitrogen } \\
(\mathrm{gm} / \mathrm{kg})\end{array}$ & $\begin{array}{c}\text { Phosphorus } \\
(\mathrm{gm} / \mathrm{kg})\end{array}$ \\
& $(\mathrm{krg})$
\end{tabular}

\begin{tabular}{llll}
\hline Green house & Open field & Green house & Open field
\end{tabular}

\begin{tabular}{ccccc}
\hline Pirimiphos-Methyl & $26.6^{*}$ & 10.6 & 6.6 & 11.1 \\
Clorpyrifos-Ethyl & 20.5 & 10.7 & 6.6 & 7.2 \\
Cypermethin & 26.7 & 10.0 & 5.6 & 11.1 \\
Fenvalerate & 18.9 & 10.3 & 6.5 & 7.5 \\
Control & 19.5 & 10.6 & 7.3 & 11.5 \\
LSD $_{\mathbf{0 . 0 5}}$ & 2.0 & 0.6 & 2.0 & 0.6 \\
\hline
\end{tabular}

* Mean of 18 samples of six weeks of three insecticide sprays at 15 days intervals.

chlorpyrifos-ethyl treated plants and control plants. The phosphorus contents reached 11.1, 7.2, 11.1 and $7.5 \mathrm{gm} / \mathrm{kg}$. D.M. in pirimiphos-methyl, chlorpyrifos, cypermethrin and fenvalerate, respectively compared with $11.5 \mathrm{gm} / \mathrm{kg}$. D.M. in the control (Table 2). The data also showed that Nitrogen content was higher in greenhouse plants than open field ones. In contrast, the level of phosphorus was higher in open field than greenhouse plants.
Effect of insecticides on trace elements of tomato plants

\section{1- Greenhouse tomato plants}

Table 3 showed significant increase of Iron content at all insecticide treatments compared with the control. The maximum content of iron was 112.9 and 112.8 $\mathrm{mg} / \mathrm{kg}$. D.M. at cypermethrin and fenvalerate treated plants. The lowest amount of iron was recorded in the control plants $(79.4 \mathrm{mg} / \mathrm{kg}$. D.M.). In the case of manganese, a dramatic effect was observed where the 
amount of manganese significantly reduced in chlorpyrifos- ethyl and cypermethrin treated plants. However, it increased significantly in pirimiphos-methyl treated plants compared with control. Data of zinc content revealed significant increase of zinc element in all insecticide treated plants compared with the control ones. Zinc content ranged between 94.1 and 111.4 $\mathrm{mg} / \mathrm{kg}$.D.M at fenvalerate and chlorpyrifos-ethyl treated plants, respectively while it was $89.6 \mathrm{mg} / \mathrm{kg}$.D.M in the control. On the other hand, significant increases were observed in copper contents in all insecticide treatments compared with the control. The copper content reached, $10.8,10.2,9.5,11.0$ and $7.7 \mathrm{mg} / \mathrm{kg} . D . M$ in pirimiphosmethyl, chlorpyrifos-ethyl, cypermethrin, fenvalerate and control, respectively.

\section{2- Open field tomato plants}

Table 3 showed significant increase in iron content at chlorpyrifos-ethyl and /or fenvalerate treatments compared with the control, while significant reduction was observed in cypermethrin treated plants. The maximum increase of iron content was with chlorpyrifos-ethyl treatment where the value reached $172.5 \mathrm{mg} / \mathrm{kg} . D . M$ and the lowest increase was at cypermethrin treatment where it was $155.5 \mathrm{mg} / \mathrm{kg}$.D.M while it was $164.7 \mathrm{mg} / \mathrm{kg} . D . M$ in the control. Data also showed significant reduction in manganese, zinc and copper contents in all insecticide treatments compared with the control. The highest reduction of manganese was recorded in chlorpyrifos-ethyl while the lowest at cypermethrin treated plants. The amount of zinc reached 46, 35.5, 51.3 and $33.9 \mathrm{mg} / \mathrm{kg} . D . M$ in pirimiphosmethyl, chlorpyrifos- ethyl and cypermethrin treated plants, respectively compared with $60.3 \mathrm{mg} / \mathrm{kg}$.D.M in the control plants. Moreover, significant differences of zinc and copper contents were observed between chlorpyrifos-ethyl and / or fenvalerate and the control (Table 3). The data also showed that the level of iron was higher in open field plants compared with greenhouse ones. However, manganese and zinc were higher in greenhouse plants than that in open field, while, the level of copper is approximately close in both open field and greenhouse plants.

The data of greenhouse tomato agree with the results of Gupta et al.(1989) and Mohmoud et al.(1996) who found that herbicide treatments reduced carbohydrate contents of wheat, lentil and soybean. However, Gaweesh and El-Bially (1991) concluded that treatment with herbicides increased carbohydrates and reported significant correlation between carbohydrates and ash content. Also, Sundaraj and Tamiselvan (1991) found that total sugar, leaf reducing sugar and total chlorophyll content increased with increasing frequency of deltamethrin application. The data of moisture and ash contents revealed no significant differences between the greenhouse treated and untreated plants. However, dramatic effects were observed between treated and untreated open field plants in which slight increase or decrease were recorded. In contrast, Sonna (1993); Hasaneen et al. (1994) and Saafan (1999) reported that pesticides has an effect on contents of water and carbohydrates in castor bean and maize plants.

Considering, the impact of pesticides on the majorelements, the data showed slight reduction of phosphorus and nitrogen contents in most of the insecticide treatments either in greenhouse or in open field plants. In the case of trace elements data showed an increase of iron, zinc and copper contents in greenhouse treated plants and reduction of manganese, zinc and copper in open field treated plants. However, dramatic effects were observed in the case of Iron in open fields and Manganese in greenhouse treated plants. In the meantime, the results of Szynal and Sykut (1993) concluded that herbicides generally increased grain $\mathrm{Ca}$, $\mathrm{K}$ content and decreased $\mathrm{Mn}$ and $\mathrm{Zn}$ contents. Furthermore, Warman and Harvard (1997) found that yield of carrots and cabbages were not affected by pesticide treatments, whereas, five elements in carrots roots $(\mathrm{N}, \mathrm{S}, \mathrm{Mn}, \mathrm{Cu}$ and $\mathrm{B})$ and two elements in carrots leaves ( $\mathrm{S}$ and $\mathrm{Na}$ ) were influenced by the treatment; in cabbages, N, Mn and $\mathrm{Zn}$ were affected.

From the previous data it is apparent that insecticides had no impact on the moisture and ash contents of open field plants. However, slight increase was observed in some insecticide treatments. The results showed an increase in the carbohydrate contents in open field plants while reduction occurred in greenhouse treated plants compared with control.

Data showed slight reduction of phosphorus and nitrogen contents in most of the insecticide treatments either in greenhouse or in open field plants. Data also showed an increase of iron, zinc and copper contents in greenhouse treated plants and reduction of Manganese, zinc and copper in open field treated plants was observed. However, dramatic effects were observed in the case of iron in open fields and manganese in greenhouse treated plants.

In general the impact of insecticides on chemical composition of tomato plants might depends on the form and availability of each element in soils, uptake and distribution within tomato plants, influence of environmental factors and the chemical structure of insecticide. 
Table3. Effect of some insecticides on trace elements of greenhouse and open field cucumber plants.

\begin{tabular}{|c|c|c|c|c|c|c|c|c|}
\hline \multirow[t]{2}{*}{ Insecticide } & \multicolumn{2}{|c|}{$\begin{array}{c}\text { Iron } \\
(\mathbf{m g} / \mathbf{k g})\end{array}$} & \multicolumn{2}{|c|}{$\underset{(\mathrm{mg} / \mathrm{kg})}{\operatorname{Manganese}}$} & \multicolumn{2}{|c|}{$\begin{array}{c}\text { Zinc } \\
(\mathbf{m g} / \mathbf{k g})\end{array}$} & \multicolumn{2}{|c|}{$\begin{array}{l}\text { Copper } \\
\text { (mg/kg) }\end{array}$} \\
\hline & $\begin{array}{c}\text { Green } \\
\text { H. }\end{array}$ & $\begin{array}{c}\text { Open } \\
\text { F. }\end{array}$ & $\begin{array}{c}\text { Green } \\
\text { H. }\end{array}$ & $\begin{array}{l}\text { Open } \\
\text { F. }\end{array}$ & $\begin{array}{c}\text { Green } \\
\text { H. }\end{array}$ & $\begin{array}{c}\text { Open } \\
\text { F. }\end{array}$ & $\begin{array}{c}\text { Green } \\
\text { H. }\end{array}$ & $\begin{array}{c}\text { Open } \\
\text { F. }\end{array}$ \\
\hline Pirimiphos-Methyl & $111.3^{*}$ & 164.1 & 106.6 & 21.8 & 96.8 & 46.0 & 10.8 & 8.7 \\
\hline Clorpyrifos- Ethyl & 104.2 & 172.5 & 75.5 & 20.0 & 111.4 & 35.5 & 10.2 & 8.0 \\
\hline Cypermethin & 112.9 & 155.5 & 70.3 & 22.5 & 99.9 & 51.3 & 9.5 & 9.0 \\
\hline Fenvalerate & 112.8 & 170.8 & 87.3 & 20.2 & 94.1 & 33.9 & 11.0 & 7.7 \\
\hline Control & 79.4 & 164.7 & 86.5 & 24.8 & 89.6 & 60.3 & 7.7 & 9.5 \\
\hline $\mathbf{L S D}_{0.05}$ & 8.6 & 5.5 & 8.4 & 1.3 & 3.7 & 2.3 & 1.1 & 0.8 \\
\hline
\end{tabular}

* Mean of 18 samples of six weeks of three insecticide sprays at 15 days intervals.

\section{Aknowledgement}

The author would like to thank King Abdulaziz City for Science \&Technology for grant fund of AT-16-105 project and Prof. M. S. Shawir for his valuable help during this work.

\section{REFERENCES}

Album,H.G. (1952). The metabolism of phosphorolated compounds in plants. Ann. Rev. Plant Physiol. 3: 35.

A.O.A.C. (1980). Official methods of analysis of the association of official analytical chemists. William Horwitz, Editor. Published by the Association of Official Analytical Chemists. Washington, DC. 20044

Cottenie, A. (1980). Soil and palnt testing as a basis of fertilizer recommendation. FAO Soils Bulletin, 38/2, FAO, Rome.

Gabr, M. A.; M. A. Shakeeb; F. A. Famy and H. Abbase (1989). Influence of metolachlor foliar spay on growth, carbohydrate content, pigmentation and photosynthetic activity in transplanted tomato plants. Egypt. J. Botany. 32 (1-2): 1-9.

Gaweesh, S. S. M. and M. E. El-Bially (1991). Yield, chemical composition and oil quality of rapeseed responses to some herbicides. Egyptian Journal of Agronomy. Special Issue, 61-70.

George, P. J. E. and D. P. Ambrose (1999). Biochemical changes by insecticides in a non-target harpactorine reduviid Rhynocoris marginatus (Fabricus). Indian J. Environ. and Toxicology. 9 (2): 78-80.

Gupta, K.; S. K. Pahwa and D. S. Wagle (1989). Effect of herbicide treatments on nitrogen and sugar contents of wheat and lentil plants. Haryna Agricultural University Journal of Research. 19 (2): 101-107.

Hasaneen, M. N. A.; H. M. El-Saht and F. M. Bassyoni (1994). Growth, carbohydrates and associated invertase and amylase activities in castor bean and maize as affected by metribuzin and $\mathrm{Na} \mathrm{Cl}$. Biologia Plantarum. 36 (3): 451-459.

Mohmoud, S. M.; S. H.Mohamed; M. M. El-Desouky and M. H. Abd-Alla (1996). Residual effect of soil application of some pesticides on growth and nodulation of soybean. Assiut Journal of Agric. Sciences. 27 (3): 83-91.

Pearson, D. (1967). The chemical analysis of foods. Seventh Edition, Churchill Livingstone Longman Group Limited, Edinburgh, London and New York.

Rajamannar, K. and L. Manohar (1998). Sublethal toxicity of certain pesticides on carbohydrates, proteins and amino acids in Labeo rohita. J. Ecobiology. 10: 185-191.

Saafan, S. E. (1999). Studies on the effect of the combined treatment of methomyl and lindane on biochemical constituents of maize plants. Egypt. J. Physiological Sciences. 22: 213-221.

Sanaa, A. R. M.; K. M. Nadia and H. E. G. Sonna (1993). The effect of vernolate, pendimethalin and pix on yield and chemical composition of peanut seeds as well as associated weeds. Bulletin of faculty of Agric. Univ. Cairo. 44: 53-70.

Sharma, H. S. S.; G. Faughey; J. Chambers; G. Lyons ans S. Sturgeon (2000). Assessment of winter wheat cultivars for changes in straw composition and digestibility in response to fungicide and growth 
regulator treatments. Annals of Applied Biology. 137: 297-303.

Snedecor,G.W. and W.G. Cochran (1967). Statistical methods. Iowa Stat College press, Ames. Iowa. U.S.A. 593 pp.

Sonna, H. E. G. (1993). Effect of gesaprim-80 alone or in combination with sulphur in controlling weeds as well as the yield and chemical composition of maize plants. Bulletin of Faculty of Agric. Univ. of Cairo. 44: 71-94.

Sundararaj, R. and C. Tamilselvan (1991). Evolution of trimethylarsine by a penicillium sp. Isolation from I: Influence of deltamethrin on some biochemical parameters in cotton leaves. Agricultural Science Digest Karnal. 11: 199-200.
Szynal, J. and A. Sykut (1993). The influence of treating wheat with herbicides on the macro and microelement content of the grain. Roczniki Nauk Rolniczych. Seria. E, Ochrona Roslin. 22 (1-2): 9196.

Um, Y. C.; N. Katsura and H. Yoshioka (1991). Changes in the sugar contents and invertase activities in young fruits of tomato and melon. Research report of the rural development Administration Horticulture. 33: 7-15.

Warman, P. R. and K. A. Harvard (1997). Yield, vitamin and mineral contents of organically and conventionally grown carrots and cabbage. Agric. Ecosystems and Environment. 61 (2-3): 155-162. 


\section{الملخص العربي}

تأثير مبيدات حشرية معينة على المكونات الكيميائية لنباتات الطماطم في الصوب والحقل المكشوف مُعمَّم بن عبد الرممن العيد

أوضحت النتائج انخفاض قليل في كل من الفسفور والنيتروجين في معظم معاملات المبيدات في كل من الصوب والحقل المكشوف. وفي حالة المعادن الصغرى أظهرت النتائج زيادة كل من الحديد والزنك منك والنحاس في النباتات المعاملة بالمبيدات داخل الصوب. وانخفـاض كـل مـن المنجنيـز والزنـك والنحــاس في نبـاتات الحقـل المكشوف المعاملة بالمبيدات. وكانت هناك تأثيرات متفاوتة للمبيدات على محتوى الحديد لنباتات الحقل المكشوف والمنجنيز في الصوب. وعموماً فإن تأثير المبيدات على المكونات الكيميائية لنباتات الطماطم ربما يعتمد على العوامل البيئية وكذلك التركيب الكيميائي للمبيد.
الكيميائية لنبـاتات الطماطم في كل مـن الصوب والحقـل المكشوف. حيـث تم تطبيق المبيدات عند المعدلات الموصى بها لمكافحة الآفات الحشرية. أوضحت النتائج عدم وجود فروق معنوية في كل من المحتوى الرطوبي والرمـاد بـين النبـاتات المعاملـة والغير معاملة بالمبيـات داخـل الصوب بينما كان هناك تأثير متفاوت للمبيدات على المتوى الرطوبي

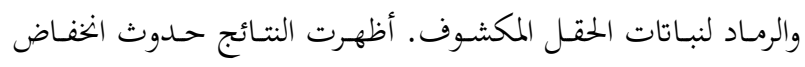
المتوى من الكربوهيدرات في جميع معاملات المبيدات داخل الصوب مقارنة بالنباتات الغير معاملة ـ كما أظهرت نباتات الحقل المكشوف المعاملة زيادة طفيفة في محتواها من الكربوهيدرات.

تم تقيسيم تأثير أربعـة مبيـات حشـرية هي البريميفسوس ميثايـل ،

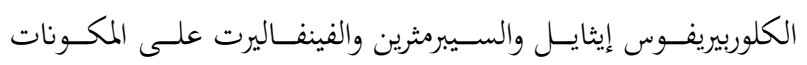

